University of Nebraska - Lincoln

DigitalCommons@University of Nebraska - Lincoln

Textile Society of America Symposium

Proceedings

Textile Society of America

$10-2020$

Schoolgirl Embroideries \& Black Girlhood in Antebellum

Philadelphia

Kelli Racine Coles

Follow this and additional works at: https://digitalcommons.unl.edu/tsaconf

Part of the Art and Materials Conservation Commons, Art Practice Commons, Fashion Design Commons, Fiber, Textile, and Weaving Arts Commons, Fine Arts Commons, and the Museum Studies Commons

This Article is brought to you for free and open access by the Textile Society of America at DigitalCommons@University of Nebraska - Lincoln. It has been accepted for inclusion in Textile Society of America Symposium Proceedings by an authorized administrator of DigitalCommons@University of Nebraska - Lincoln. 


\title{
Schoolgirl Embroideries \& Black Girlhood in Antebellum Philadelphia
}

\section{Kelli Racine Coles}

krcoles@udel.edu

\author{
"The well-taught philosophic mind \\ To all compassion gives \\ Casts round the world an equal eye \\ And feels for each that lives."
}

Eight-year-old Mary D'Silver stitched this verse into a diminutive sampler in 1793 (Figure 1). The education D'Silver received as a student is exemplified with the inclusion of this verse. The verse is an excerpt from the 1772 poem "The Mouse's Petition" by British poet and essayist, Anna Laetitia Barbauld. ${ }^{1}$ Whether D'Silver or her teacher selected this verse is unknown. Nonetheless, this poem no doubt had an effect on D'Silver as she likely meditatively stitched its words with colorful silk threads into her linen canvas. D'Silver was witnessing the plight of Philadelphia's Black enslaved and free communities all around her. ${ }^{2}$ Literary scholars Katherine Capshaw and Anna Mae Duane note that scholars of childhood literature and childhood studies have emphasized the necessity to "imagine children as active readers, agents who are fully capable of bringing critical and imaginative reading faculties to the texts they engaged."

\footnotetext{
${ }^{1}$ Barbauld utilizes the rhetoric of the abolitionist movement to criticize the divisions between the rich and poor, and nods to the burgeoning animal rights movement. Unfortunately, many scholars and people in the eighteenth-century society misread the poem to be about the cruelty of animal experimentation at the time. Barbauld was upset by society's literal reading of her poem according to scholar Katherine Ready in her article "What then, poor Beastie!": Gender, Politics, and Animal Experimentation in Anna Barbauld's 'The Mouse's Petition'” in the journal, Eighteenth-Century Life 28, no. 1 (April 8, 2004): 92-114. Barbauld clarified her poem was referring to "mercy" and "justice" rather than to "humanity" and "cruelty." It was additionally requoted in 1773 publications in defense of the protests against animal experimentation.

${ }^{2}$ In this paper I am purposefully capitalizing the "B" in Black when referring to people of color of African descent and using a lower case " $w$ " for people who are largely of European descent. Black is capitalized to represent the group of people whose ancestors were born on the continent of Africa, taken against their will and brought to the Americas in the past 400 years. I am not speaking about the color black. As Lori L. Tharp states in her essay written on her blog and later for the New York Times, I am giving Black people the same respect and acknowledgement at Asians, Latinos, Native Americans, and many other ethnic groups around the world. I decided not to capitalize white because it does not have the same classification for a group of people as Black does for people of the African diaspora especially during the eighteenth and nineteenth centuries in North America. People of European descent often still referred to themselves by their ethnicities of Irish, Italian, British, Welsh, Dutch and so forth. See blog post on Ask A Radical Copyeditor entitled "Black with a Capital "B" https://radicalcopyeditor.com/2016/09/21/black-with-a-capital-b/. It is from this post that I also referenced Lori L. Tharps' "I Refuse to Remain in the Lower Case" on My American Melting Pot, http://myamericanmeltingpot.com/2014/06/02/i-refuse-to-remain-in-the-lower-case/, her New York Times article, "The Case for Black with a Capital B" https://www.nytimes.com/2014/11/19/opinion/the-case-for-black-with-acapital-b.html. And Toure's book, Whose Afraid of Post-Blackness?: What I Means to Be Black Now, vii.

${ }^{3}$ Katharine Capshaw and Anna Mae Duane, "Introduction: The Radical Work of Reading Black Children in the Era of Slavery and Reconstruction," in Who Writes for Black Children?: African American Children's Literature before 1900 (Minneapolis, MN: University of Minnesota Press, 2017), xii.
} 
Focusing on needlework stitched by Black girls reveals how Black girls were being groomed for womanhood in the midst of the formation of a white supremacist society grappling with the place

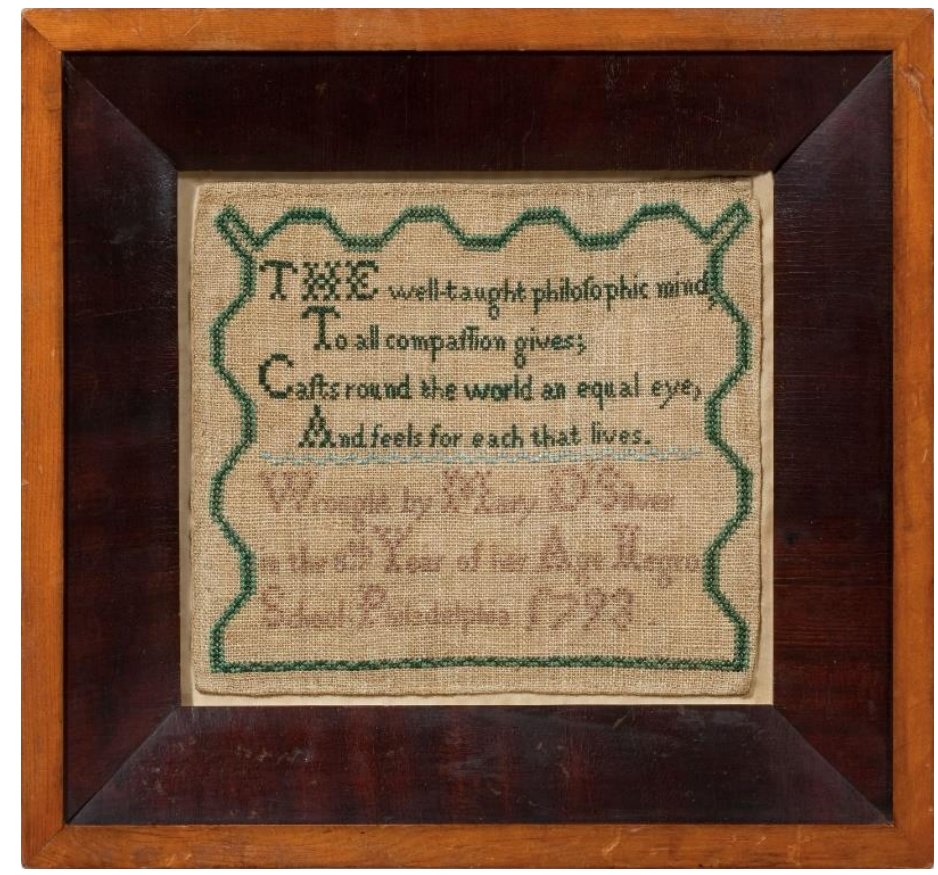

Figure 1: Courtesy, Winterthur Museum, Marking sampler by Mary D'Silver at Bray Associates Negro School, Philadelphia, PA, 1793, Silk on Linen, Museum purchase with funds provided by the Henry Francis du Pont Collectors Circle, 2014.33.

of free and newly freed Black Americans demanding full citizenship rights. As Laurel Thatcher Ulrich states, needlework was simultaneously a site of cultural production and field of personal expression. ${ }^{4}$ Needlework made by Black girls provides valuable clues about the lives of Black girls, their education, and the communities in which they lived during the antebellum period. The samplers and girlhood embroideries they created illuminate the girls' possible utilization of needlework knowledge and textile production inherited by them extending back to African traditions. Therefore, needlework stitched by Black girls reveal the many sources of inspiration, African and European, which Black girls may have pulled from in their creation of themselves and the world around them.

Needlework illuminates the presence of Black girls that have largely been ignored in historical scholarship. The apparent lack of archival evidence on the lives of Black girls resulted in this absence within historical scholarship. Capshaw and Duane states, "black children in early America were excluded from nearly every category recognizable to scholars." 5 Saidya Hartman explains this absence of archival evidence centering Black girls and women as the "violence of the archives." The voices and bodies of Black girls and women are silenced, commodified, insulted, and defamed in archival records predominately written from the perspective and gaze of

\footnotetext{
${ }^{4}$ Laurel Thatcher Ulrich, The Age of Homespun: Objects and Stories in the Creation of an American Myth (Vintage, 2009), 40.

${ }^{5}$ Capshaw and Duane, Who Writes for Black Children?, xi.
} 
white men. ${ }^{6}$ In addition to this violence, a "culture of dissemblance" that Black American females understandably adhered to leave the archives void of Black girls' voices. ${ }^{7}$ However, Black girls have left evidence of their presence through their needlework. Psychologist Puleng Segalo states, "embroidery is one of the many forms of visual methods that can represent and narrate lived realities visually." Alice Walker's In Search of Our Mother's Garden and Jean Yellin Fagan's essay in the feminist anthology, All the Women are White, All the Men are Black, But Some of Us Are Brave: Black Women's Studies considered the importance of centering Black girls and women, as well as the needlework they created. ${ }^{9}$ In the past two decades scholars of Black women and Black girlhood, such as Saidiya Hartman, Marisa Fuentes, Jessica Marie Johnson, Nazera Wright, LaKisha Simmons, and Marcia Chatelain, have located the historical presence of Black girls and women, their voices, and experiences. ${ }^{10}$ Additionally, Lisa Farrington centers the art of Black women in her scholarship and seeks to, "deconstruct the persistent falsehoods that have dogged black female iconography." 11 Needlework as physical testaments of the antebellum Black girls' educational accomplishments, respectability, domesticity, and their personal values, further deconstructs the negative stereotypes laid against Black girls and woman. The definition and vision of domestic creative work are expanded when Black girls and young women are centered. The idealized visions of white women and girls creating beautiful needlework within their homes and schools only tells part of the story of domestic work in the eighteenth and nineteenth century. Furthermore, when girls, such as, Mary D'Silver and their needlework are centered as historical subjects, a nuanced understanding is gained of the burgeoning cultures of antebellum Black American communities, as well as American society as a whole.

Black girls creating samplers and girlhood embroideries, as well as the evidence of the formation Black American children's education has been muffled by needlework scholarship adhering to a white supremacist ideology. Just as Black girls were seldom centered in historical scholarship,

\footnotetext{
${ }^{6}$ Saidiya Hartman, "Venus in Two Acts." Small Axe: A Caribbean Journal of Criticism Small Axe: A Caribbean Journal of Criticism 26, no. 3 (2008), 2.

${ }^{7}$ Darlene Clark Hine, "Rape and the Inner Lives of Black Women in the Middle West: Preliminary Thoughts on the Culture of Dissemblance.” Signs 14, no. 4 (1989): 912-20. Hine explained this dissemblance as a reaction to the racial and sexual violence Black women and girls received at the hands of their white owners and peers. Black girls and women hide their subjectivities behind a veil of protection, which Hine termed a "culture of dissemblance." ${ }^{8}$ Puleng Segalo, "Women Speaking through Embroidery: Using Visual Methods and Poetry to Narrate Lived Experiences.” Qualitative Research in Psychology 15, no. 2-3 (July 3, 2018), 299.

https://doi.org/10.1080/14780887.2018.1430013.

${ }^{9}$ Walker believes a girl or woman creates to feed her soul and to order the universe in her personal concept of Beauty in In Search of Our Mothers' Gardens: Womanist Prose, (San Diego: Harcourt Brace Jovanovich, 1983), 241.

${ }^{10}$ They utilize literary texts, reading "against the grain" and "along the biased grain" in the archives, the built environment, photography, and geography. See Saidiya Hartman, Scenes of Subjection: Terror, Slavery, and SelfMaking in Nineteenth Century America, 1997 and Wayward Lives, Beautiful Experiments: Intimate Histories of Social Upheaval, 2019; Marisa J. Fuentes, Dispossessed Lives: Enslaved Women, Violence, and the Archive, 2016; Jessica Marie Johnson, Wicked Flesh: Black Women, Intimacy, and Freedom in the Atlantic World, 2020; Nazera Wright, Black Girlhood in the Nineteenth Century, 2016; LaKisha M. Simmons, Crescent City Girls, 2015; Marcia Chatelain, South Side Girls, 2015; Tammy Owens, Durell Callier, Jessica Robinson, and Porshe Garner, "Towards an Interdisciplinary Field of Black Girlhood Studies" in Departures in Critical Qualitative Research, 2017; Kabria Baumgartner, In Pursuit of Knowledge, 2019; and Crystal Webster, "The History of Black Girls and the Field of Black Girlhood Studies: At the Forefront of Academic Scholarship | The American Historian,” 2020.

${ }^{11}$ Lisa E. Farrington, Creating Their Own Image: The History of African-American Women Artists, (Oxford, England: Oxford University Press, 2005), 4.
} 
their lives, and the needlework they created are seldom centered in needlework scholarship of the United States. Although examples of samplers and girlhood embroideries created by Black girls are rare, they do exist within the same archives and collections as needlework created by white girls. Scholars have centered hundreds, if not thousands of white girls, the needlework they created, the schools they attended, the teachers that taught them needlework, and their families in their scholarship. However, that same depth of scholarship cannot be found for Black girls who also created similar samplers and girlhood embroideries. ${ }^{12}$

The importance of needlework as a skill for domestic uses and employment is considered by centering the samplers and girlhood embroideries created by Black girls. Free and enslaved Black American girls would have valued needlework as a skill to gain financial independence and to help care for their families. Gloria Seaman Allen states that sewing was regarded by many as a practical skill for daughters of the working class. ${ }^{13}$ Black American women could and did work as seamstresses, dressmakers, and milliners in the eighteenth and nineteenth centuries. ${ }^{14}$ In urban settings across the Americas, Jennifer L. Morgan explains how some enslaved women embraced the opportunity, though limited, to move about their cities unsupervised. In Philadelphia, Gary Nash, revealed that in the 1795, 1811, and 1816 city directories, seamstress was one of the professions one quarter of the Black people listed. ${ }^{15}$ Free and enslaved Black women relied on these professions because systemic racism barred them from employment available to white women. Nash highlights how free Black women and men were barred from working in the Philadelphia factories of new industrial entrepreneurs and founders of textile mills and other factories that hired almost exclusively native-born and immigrant white women and men. ${ }^{16}$ Instead, many Black women honed their needlework skills and pursued independent ventures to support themselves and the livelihoods of their families and friends.

\footnotetext{
${ }^{12}$ These are the books and articles that I have found thus far that mention needlework made by Black girls and young women: Ethel S. Bolton, Eva J. Coe, and Massachusetts Society of the Colonial Dames of America, American Samplers, 1921; Gloria T. Hull, Patricia Bell-Scott, and Barbara Smith, All the Women Are White, All the Blacks Are Men, but Some of Us Are Brave: Black Women's Studies, 1982; Cooper-Hewitt Museum, Gillian Moss, and Scott Hyde, Embroidered Samplers in the Collection of the Cooper-Hewitt Museum, 1984; Gloria S. Allen, "African American Samplers from Antebellum Baltimore" in The Magazine Antiques, 2004; Carol Schoettler, "Stitches in Time" in The Baltimore Sun, 2004; Connecticut Historical Society and Susan Schoelwer, Connecticut Needlework: Women, Art, and Family, 1740-1840, 2010; Gloria S. Allen, A Maryland Sampling: Girlhood Embroidery 1738-1860, 2007; Interview with Linda Eaton and Amy Finkel in "Endnotes: African American Schoolgirl Embroidery" in The Magazine Antiques; Amy Finkel, Samplings: Antique Samplers \& Silk Embroideries from M. Finkel \& Daughter, 2021; Tonya Bolden, Tell All the Children Our Story: Memories and Mementos of Being Young and Black in America, 2001; and Lynne Anderson "Transnational Influences on Louisiana Samplers: Traditions, Teachers, Techniques, and Text" in the Textile Society of America Symposium Proceedings, 2016. ${ }^{13}$ Gloria Seaman Allen, A Maryland Sampling: Girlhood Embroidery 1738-1860 (Baltimore, Md: The Maryland Historical Society, 2007), 238.

${ }^{14}$ There are a few narratives of the nineteenth century that center the work of Black women and their needlework or textile production. See Harriet E. Wilson, P. Gabrielle Foreman, and Reginald H. Pitts, Our Nig, or, Sketches from the Life of a Free Black, 2009; Elizabeth Keckley, Behind the Scenes, or Thirty Years A Slave, and Four Years in the White House, 2011; Rebecca Jackson, Gifts of Power: The Writings of Rebecca Jackson, Black Visionary, Shaker Elderess, 1987; in addition to, Thavolia Glymph, Out of the House of Bondage: The Transformation of the Plantation Household, 2003; Jennifer Morgan, Laboring Women: Reproduction and Gender in New World Slavery, 2004; and Alice Walker, "Gifts of Power: The Writings of Rebecca Jackson" in In Search of Our Mothers' Gardens, Womanist Prose, 1983.

${ }^{15}$ Gary B. Nash, Forging Freedom: The Formation of Philadelphia's Black Community, 1720-1840 (Cambridge, Mass.: Harvard University Press, 1988), 150.

${ }^{16}$ Nash, Forging Freedom, 145.
} 
On the Southern plantations of the United States textile production and needlework knowledge were also valued skills. ${ }^{17}$ Karen Hampton argues that the Southern textile industry would not have been possible without skilled free and enslaved Black women and girls, who became "female Negro textile artisans." 18 The women and girls worked cotton and indigo fields, in plantation spinning rooms, loom houses, and textile mills. ${ }^{19}$ Hampton found, in general, women and girls on Southern plantations often worked to clothe themselves, their families, their enslavers, and for bartering to sustain themselves. ${ }^{20}$ Similarly, Thavolia Glymph cites from the North Carolina Narratives the stories of two women's mothers who used their needlework and textile production knowledge to sell their wares in the markets. "Hanna Plumer's mother made bed clothes, bonnets, and dresses to earn cash. Fannie Moore's mother, a field hand, quilted and spun thread at night after working in the fields during the day in order to be able to purchase items her owners did not supply." ${ }^{21}$ Black girls and women would take their needlework skills learned and honed on the Southern plantations with them when they migrated west and north. Nash discusses how many Black Philadelphians at the beginning of the nineteenth century shared a "background in southern slavery, a flight north, and a search for subsistence in urban places that required the acquisition of varied skills and frequent changes of residence." 22 In addition, Nash notes the one hundred and thirty-four formerly enslaved African individuals from two ships of illegal traders and approximately five hundred formerly enslaved French-speaking individuals from Saint Domingue that populated the city of Philadelphia by the beginning of the nineteenth century. ${ }^{23}$ Altogether, these skills and knowledge could also be traced further back in time to the birthplace of them or their ancestors to societies on the African continent.

The needlework scholarship of American samplers and girlhood embroideries have often overlooked the possible contribution of African traditions, besides the beautiful works produced in the northern country of Egypt. ${ }^{24}$ For instance, Gloria Seaman Allen states "the girlhood

\footnotetext{
${ }^{17}$ See Gloria S. Allen, "Slaves as Textile Artisans: Documentary Evidence for the Chesapeake Region" in American Quilt Study Group, 2001 and Daina Ramey Berry, “'She Do a Heap of Work': Female Slave Labor on Glynn County Rice and Cotton Plantations" in The Georgia Historical Quarterly, 1988.

${ }^{18}$ Karen Hampton "African American Women: Plantation Textile Production from 1750 to 1830." Approaching Textiles, Varying Viewpoints: Proceedings of the Seventh Biennial Symposium of the Textile Society of America 770 (2000): 262.

${ }^{19}$ Hampton, “African American Women...," 266. Hampton notes that at Monticello's Mulberry Row, female enslaved girls began learning in the spinning rooms and loom houses at ten years old.

${ }^{20}$ Hampton, 264.

${ }^{21}$ Thavolia Glymph Out of the House of Bondage: The Transformation of the Plantation Household (Cambridge, UK: Cambridge University Press, 2003), 189.

${ }^{22}$ Nash, Forging Freedom, 134.

${ }^{23}$ Nash, 139-140. They were freed and indentured out for a term because the Pennsylvania Abolition Society believed it was the best way they would become accustom to Philadelphian society.

${ }^{24}$ Scholar Basil Davidson would argue this was due to Europeans justifications of slavery, the slave trade, and the beginnings of modern racism. (See Basil Davidson, Black Mother: The Years of the African Slave Trade, (United Kingdom: Penguin Books), 1980) Europeans could not deny the many advances in art, science, architecture, and math made in the ancient Egyptian civilization. Therefore, there was great controversy among Egyptologists in which many believed that Egypt could not be a Black/African civilization. A Black civilization could not be so advanced and therefore anything that was exceptional in African countries was attributed to having European roots. Davidson states, in Old Africa Rediscovered, "time and again, the achievements of men in Africa - men of Africa have been laid at the door of some mysterious but otherwise unexplained 'people from outside Africa'... a whole galaxy of non-African people are dragged in to explain it. The Phoenicians are brought in to explain Zimbabwe in Rhodesia. The Egyptians are produced as painters of the "white lady" of the Brandberg in southwest Africa. Greeks or Portuguese are paraded as the inspirers and teachers of those who worked in terracotta and worked in bronze in
} 
embroidery of Maryland, like that of the South, grew out of the tradition of English needlework" with additional influences from German immigrants, French immigrants after the French Revolution, French-Caribbean emigres after the Haitian Revolution, and Quakers from Pennsylvania. Only the rigorous needlework training of Europe is acknowledged in the text. ${ }^{25}$ Allen describes the embroidery as a pastime of accomplished white women, and thereby a new, foreign needlework skill taught to the Black schoolgirls of the Oblate Sisters of Providence in Baltimore. ${ }^{26}$ Interestingly, textile scholars of African textile history have identified needlework practiced in many African societies. ${ }^{27}$ For instance, there is a long history of embroidery, and textile production more broadly, in West Africa. This section of the African continent is the ancestral homeland of the greatest majority of Africans who were taken to be enslaved in the Americas. Art historian Victoria L. Rovine notes that embroidery, as a central element of dress practices in West Africa, socially elevated garments both visually and symbolically. Embroidered clothing revealed a person's religious practices and social identity, locating them in global trade networks. ${ }^{28}$

Textile production and embroidery expertise traveled across the Atlantic with people forcibly enslaved in the Americas. Needlework knowledge was likely passed down through the generations and brought with ancestors, grandparents, parents, or possibly some of girls themselves, across the Atlantic from their African home villages and tribes. Free and enslaved people exhibited their knowledge of textile production and needlework through the work they performed throughout the American colonies during the antebellum era. ${ }^{29}$ This needlework knowledge would have been embodied in the creation of household linens, quilts, clothing, hats, and other accoutrements, as well as the ability to mark such items to distinguish one's personal property from another on wash days. The girls garnered this familial knowledge and then honed their skills under the instruction of their needlework teachers.

Mary D'Silver's process of learning needlework possibly first learned at home and then improved in school is unknown due to the violence of the archives. However, her needlework accomplishments at the age of eight-years-old are known through the material evidence of her sampler. The sampler is a natural-colored, plain woven linen ground worked with silk threads of

medieval West Africa. (1959:31) (See also Cheik Anta Diop, The African Origin of Civilization: Myth or Reality, (New York: L.Hill), 1974; Martin Bernal, Black Athena: The Afroasiatic Roots of Classical Civilization, (New Brunswick: Rutgers University Press), 1987; Wunyabari Maloba, "History of Africa" September 21, 2016 class lecture; and for a rebuttal argument, see Mary Lefkowitz, Not Out of Africa: How Afrocentrism Became an Excuse to Teach Myth as History (New York: Basic Books), 1996.

${ }^{25}$ Allen, A Maryland Sampling, 2.

${ }^{26}$ Allen, 246.

${ }^{27}$ See Foster, Helen B, New Raiments of Self: African American Clothing in Antebellum South (New York: Berg) 1997; Sarah C. Brett-Smith, The Silence of the Women: Bamana Mud Cloths (Milan, Spain: 5 Continents Editions), 2014; Dale Idiens, Textiles of Africa (Bath: Pasold Research Fund), 1980; and John Picton and John Mack, African Textiles: Looms, Weaving, and Design (London, UK: British Museum Publications for the Trustees of the British Museum), 1979.

${ }^{28}$ Victoria L. Rovine, "West African Embroidery: History, Continuity, and Innovation" in Africa Interweave: Textile Diasporas, exhibition catalog edited by Susan Cooksey (Gainesville, FL: Samuel P. Harn Museum of Art, University of Florida, 2011), 57.

${ }^{29}$ See also Karol K. Weaver, "Fashioning Freedom: Slave Seamstresses in the Atlantic World." Journal of Women's History, 24:44-59; and "Syllabus." Rendering Revolution: Sartorial Approaches to Haitian History, https://renderingrevolution.ht/syllabus featuring a list of sources discussing the importance of dress, materiality, and textiles around the Haitian Revolution. 
green, red, and blue and is displayed in a wood frame, not original to the piece (Figure 1$).^{30}$ The materiality of eight-year-old Mary D'Silver's sampler is evidence that the school administrators, school mistress, and her parents did not skimp on purchasing the customary materials of linen canvas and silk threads for her needlework. These materials would have been the same materials her white schoolgirl counterparts utilized in their needlework of the same era. D'Silver utilized cross and eyelet stitches throughout the verse stitched in green silk. Stitched in red silk, the identification section of the sampler reads: Wrought by Mary D'Silver/in the $8^{\text {th }}$ Year of her Age Negro/School Philadelphia 1793. The verse and identification are surrounded by a zig-zag border, an ancient design motif signifying day and night, the changing seasons, or flowing water according to needlework scholar, Margaret Schiffer. ${ }^{31}$ The border was stitched utilizing cross or marking stitches in two shades of green silk. This sampler was previously identified as a marking sampler. However, D'Silver's sampler does not feature the customary alphabets and numbers. It is more likely to be a fundraising piece for the Associates of Dr. Bray's Negro School in Philadelphia. ${ }^{32}$ There are a few threads that lead to a connection between Mary D'Silver, her family, and the Associates of Dr. Bray in Philadelphia. This conclusion is further supported by the sampler being found in the early twenty-first century in the attic of a family in London, England. The Associates of Dr. Bray are a London-based Anglican organization. It is highly likely that the British family's ancestor supported the work of the Associates of Dr. Bray and their Negro School in the city of Philadelphia with the purchase or reciprocal gift of D'Silver's sampler. ${ }^{33}$

The Associates of Dr. Bray's Negro School, in the city of Philadelphia was established in 1758 by the London-based Anglican organization with the assistance of Benjamin Franklin and administered by Reverend William Sturgeon of Christ Church. It was a co-educational institution for free and enslaved children of color in the city. ${ }^{34}$ The Associates of Dr. Bray was established in 1724 specifically to convert and educate enslaved African children of the British colonies. ${ }^{35}$ Boys and girls were instructed in how to read at the school and required to attend church on Wednesdays and Fridays. Additionally, the girls were instructed in how to sew, knit, and

30 Winterthur Museum Collection Digital Database. File: 2014.0033 A-B. Sampler (Marking Sampler).

${ }^{31}$ Margaret Berwind Schiffer, Historical Needlework of Pennsylvania (New York: Scribner, 1968), 15. The culture of this ancient design motif is not specified in Schiffer's text but is a detail I hope to discover in my research. 32 According to W. E. B. Du Bois, Elijah Anderson, and Isabel Eaton, The Philadelphia Negro: A Social Study, (Reprint. Philadelphia, PA: University of Pennsylvania Press, 1996), 84, there were a few educational institutions in the city of Philadelphia at the end of the eighteenth century named Negro School. There was a Negro School later named the Raspberry School founded in 1770 by Anthony Benezet, James and Israel Pemberton, Henry Drinker, Joseph Marriot, and Daniel Stanton. There was also the Pennsylvania Abolition Society's Committee of Education founded a co-educational Negro School on Cherry Street in 1793 in which Black American schoolteacher Eleanor Harris taught spelling, reading, and needlework according to John C. Van Horne "The Education of African Americans in Benjamin Franklin's Philadelphia” in “The Good Education of Youth”: Worlds of Learning in the Age of Franklin, edited by John Pollack, (Philadelphia, PA: Oak Knoll Press, University of Pennsylvania Libraries, 2009), 88.

${ }^{33}$ I am deeply grateful for the research and conversations I have had with Linda Eaton and Amy Finkel in establishing this connection between the D'Silver family, the British family, and the Associates of Dr. Bray.

${ }^{34}$ John C. Van Horne and Associates of Dr. Bray. Religious Philanthropy and Colonial Slavery: The American Correspondence of the Associates of Dr. Bray: 1717-1777 (Urbana, Chicago, IL: University of Illinois Press, 1985), 135 .

${ }^{35}$ Brendan Wolfe, “Associates of Dr. Bray” in Encyclopedia Virginia. Virginia Humanities, 2017, https://www.encyclopediavirginia.org/Associates_of_Dr_Bray. The Society for Promoting Christian Knowledge (SPCK) established by Bray in 1699 and the Society for the Propagation of the Gospel in Foreign Parts (SPGFP) established by Bray in 1701 were performing similar work in colonized lands for Indigenous people and for native English people in England, respectively. 
embroider. ${ }^{36}$ Erica Armstrong Dunbar notes, "in general, primary education for all classes remained elusive before the Revolution, which makes the inclusion of young black girls in these early colonial schools all the more notable." 37 The school cosed during the Revolutionary War in 1775, then reopened after the war in 1786 under the administration of Benjamin Franklin, Francis Hopkinson, and schoolmistress, Ruth Lewis. Bishop William White assumed administration of the school in 1791 after the death of Franklin and Hopkinson. ${ }^{38}$ The same Bishop White performed the marriage of Mary's parents, Emanuel D'Silver and Judith Jones in 1783, and baptized Mary after her birth on January 13, 1785, according to the records of Christ Church. ${ }^{39}$

This introduction to Mary D'Silver's life is one of the many stories I weave together on the education and needlework skills of enslaved and free Black girls and young women in the antebellum era of the nascent United States. The second embroidery stitched by a Black schoolgirl belongs to Adaline Harris (Figure 2). She stitched her sampler in 1830 as a student at the Pennsylvania Abolition Society's Clarkson School in Philadelphia. Adaline Harris's sampler is silk embroidered on a linen ground. ${ }^{40}$ The sampler features a strawberry vine around the perimeter of the canvas, a verse at the top centered in the canvas, and a pastoral scene below the verse.

The six lines of the verse read:

A solitary blessing few can find

Our joys with those we love are intertwin'd

And he whose wakeful tenderness removes

The obstructing thorn which wounds the friend he loves

Smooths not another's rugged path alone

But scatters roses to adorn his own.

Below her verse, Harris signed her work: Adaline Harris/Clarkson School/10 ${ }^{\text {th }}$ mo $1^{\text {st }} 1830$. The verse is from the essay, "Sensibility: A Poetical Epistle to the Hon. Mrs. Boscawen," the 1782 moral guide of English poet, playwright, teacher, and philanthropist Hannah More. This verse, central to the abolitionist's cause of ending the enslavement of Black people, spoke to the joy one feels when relieving a friend's pain or suffering. Below the verse is a pastoral scene of a white, male shepherd and his dog tending to two ewes, a goat, and a ram beneath a tree. While the connection between the verse and the imagery is yet to be discovered, More did write

\footnotetext{
${ }^{36}$ Van Horne, Religious Philanthropy and Colonial Slavery, 83. Reverend Sturgeon was the assistant minister at Christ Church and catechist to Black people in Philadelphia supported by the Society for the Propagation of the Gospel in Foreign Parts (SPGFP); Reverend John Waring was the secretary for the Associates of Dr. Bray in London, England. A schoolmistress was hired to instruct the children according to correspondences between Rev. Sturgeon and Rev. John Waring in London.

${ }^{37}$ Erica Armstrong Dunbar, A Fragile Freedom: African American Women and Emancipation in the Antebellum City (New Haven: Yale University Press, 2008), 53.

${ }^{38}$ Van Horne, "The Education of African Americans in Benjamin Franklin's Philadelphia," 84, 88. They opened schools in New York and Williamsburg, Virginia in 1760, a school in Newport, Rhode Island in 1762, and the final school in Fredericksburg, Virginia in 1765. The Associates of Dr. Bray were so happy with the success they saw at the Negro School in Philadelphia that they decided to open four more schools in the colonies.

${ }^{39}$ Christ Church of Philadelphia, Register of Marriages, 1709-1800, 4447; Christ Church of Philadelphia, Register of Baptisms, 1769-1794, 1220. Mary's father's name was also spelled DeSylva. Her baptism record spelled her name as Desylva and her parents as Desylvus.

${ }^{40}$ Harris's sampler is approximately seventeen and one-quarter inches square.
} 
pastoral plays for young women to act out while she was teaching. ${ }^{41}$ Therefore, this imagery may be a copy of a woodcut or engraving of a scene from one of her plays.

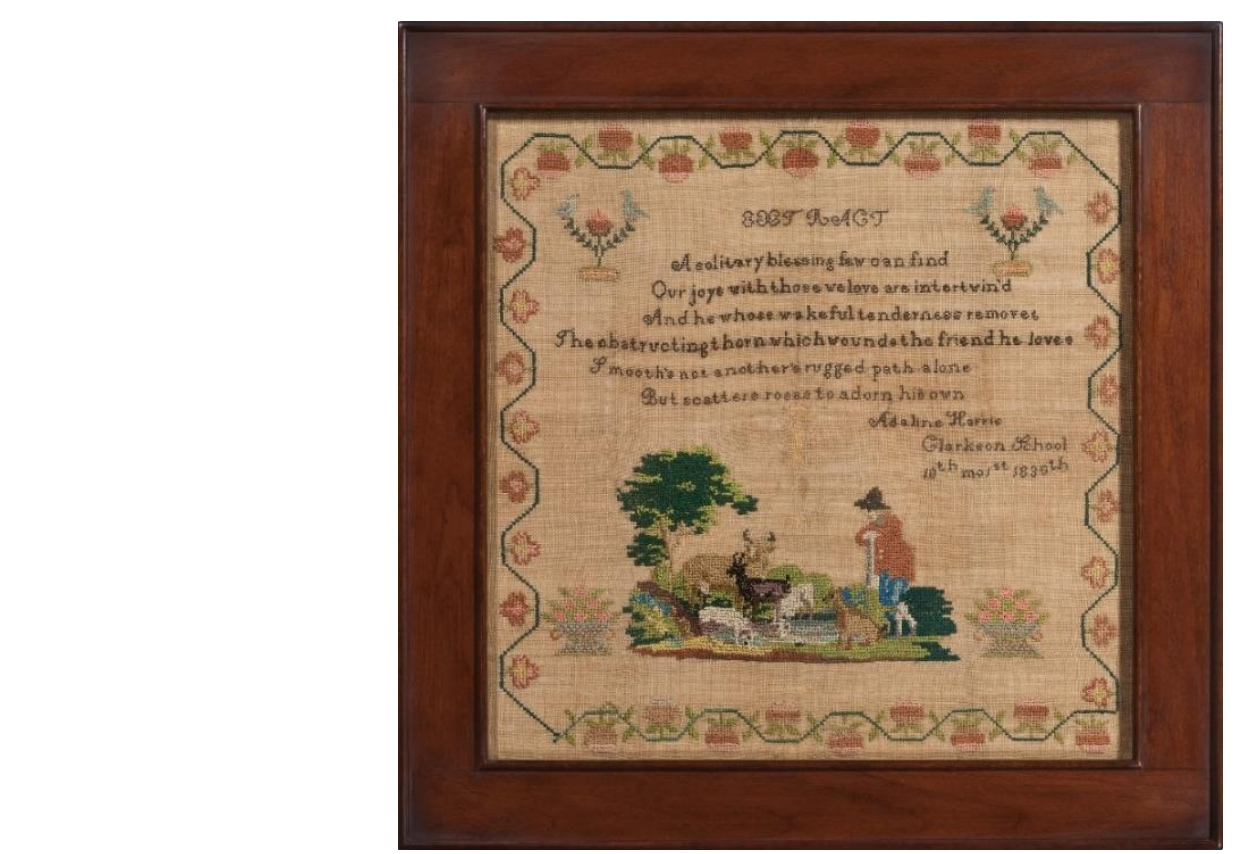

Figure 2: Courtesy of the collection of Leslie Anne Miller; Silk embroidery on linen ground by Adaline Harris, dated "1830," Philadelphia, PA; Silk \& Linen.

Adaline Harris stitched this beautiful sampler at the age of fourteen as a student at the Clarkson School in Philadelphia. The Clarkson School was founded by the Pennsylvania Abolition Society's Board of Education in 1813 for young, free Black children in the city of Philadelphia. Benjamin Franklin worked towards the abolition of slavery and the education of children of color, as a founder of the Associates of Dr. Bray's Negro School and as a president of the Pennsylvania Abolition Society. Unfortunately, he died prior to the founding of the Clarkson School on Cherry Street between $6^{\text {th }}$ and $7^{\text {th }}$ Streets in Philadelphia. ${ }^{42}$ Harris attended classes at Clarkson between November 1828 and June 1833 under the tutelage of teacher Elisabeth Reynolds. At the time Harris was living near Ninth and Vine Streets, which was then on the edge of the neighboring city, Spring Garden. ${ }^{43}$

By the 1850s, needlework was no longer a mandatory subject of educational curriculum, but it was still taught in many schools as a necessary skill to attain for future domestic and financial

\footnotetext{
${ }^{41}$ S. J. Skedd, "More, Hannah (1745-1833), Writer and Philanthropist," in the Oxford Dictionary of National Biography. Accessed January 26, 2021. https://doi.org/10.1093/ref:odnb/19179.

${ }^{42}$ Convention of Delegates from the Abolition Societies Established in Different Parts of the United States. 1797. Minutes of the Proceedings of a Convention of Delegates from the Abolition Societies Established in Different Parts of the United States, Vol. 4 (Philadelphia, PA: Zachariah Poulson), 1797), 32. The schoolmistress at the time of its founding was Elizabeth Clendenin.

${ }^{43}$ Pennsylvania Abolition Society Papers, "Pennsylvania Abolition Society Board of Education, Clarkson School Entrance of Girls 1828-1838." AMS.183. 0490. This area of the city is now known as the Chinatown section of Philadelphia. Adaline Harris's name appears in the "Pennsylvania Abolition Society's Board of Education, Clarkson School Entrance of Girls, 1828-1838” book, as cited in Sumpter Priddy's 2017 unpublished report on Harris. I am grateful for the research on Adaline Harris conducted by Sumpter Priddy III, Inc in collaboration with Weckea Dejura Lilly, researcher, at the Historical Society of Pennsylvania.
} 
opportunities for young Black girls and women. Olevia Rebecca Parker worked her pictorial canvaswork embroidery in 1852 when she was fourteen years old and a student at the Lombard Street School (Figure 3).

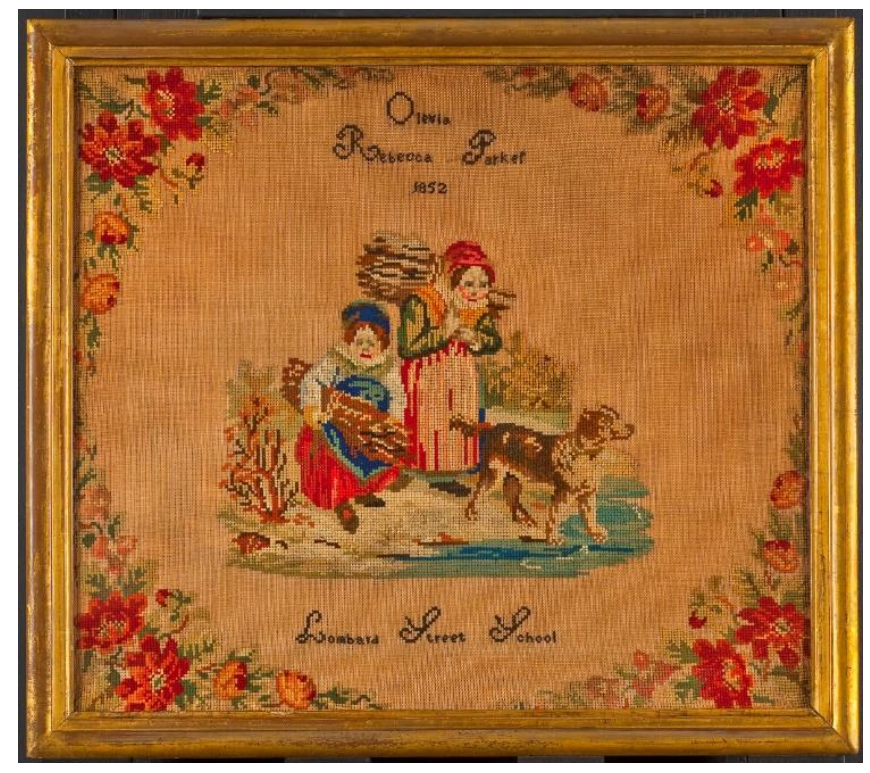

Figure 3: Courtesy, Winterthur Museum, Canvaswork picture by Olevia Rebecca Parker, 1852, Philadelphia, PA, Wool, Cotton, Museum purchase with funds provided by the Henry Francis du Pont Collectors Circle, 2009.12.1.

Stitched in polychrome wool crewel yarns on a natural, plain-woven cotton canvas, the embroidery consists of an oval floral border surrounding two white children and their dog, gathering wood near a shoreline. Above the image centered on the canvas, Parker stitched her signature line: Olevia/Rebecca Parker/1852. And below the image also centered on the canvas she added: Lombard Street School. Parker utilized tent and cross stitches to complete her piece. She chose a finer yarn to render the children's faces and hands in detail. The canvaswork embroidery is in its original strainer and its original gilt frame, a rarity. ${ }^{44}$ It is evident the Parker family cherished the schoolgirl embroidery of Olevia Rebecca Parker because of the survival of both the frame and strainer. Unfortunately, the source of Parker's chosen imagery also remains undiscovered.

Olevia Rebecca Parker was born in Philadelphia in 1838 to Adam and Olivia Parker. In 1852, at fourteen years of age, Parker completed her embroidery while a student at the Lombard Street School, under the direction of two well-respected white teachers in the Black community: principal James M. Bird and girls' school director Maria C. Hutton. ${ }^{45}$ The Philadelphia Board of Education established Lombard Street as a segregated public school for children of color in 1828. Benjamin C. Bacon's report, "Coloured School Statistics" notes the Lombard Street School's "ornamental needlework and lace knitting of the girls cannot be surpassed by any

\footnotetext{
${ }^{44}$ The embroidery measures twenty-one and a half inches by twenty-four and a half inches inside of the frame.

${ }^{45}$ Philadelphia Board of Education, Minutes of the directors of public schools, 1827-1841, 33, 35. This is cited in Henry C. Silcox, "Delay and Neglect: Negro Public Education in Antebellum Philadelphia, 1800-1860" in The Pennsylvania Magazine of History and Biography, Vol. 97:4, 1973, 444-464.
} 
school at similar grade." Bacon also commended the girls' recitation and copy books for their neatness and quality. ${ }^{46}$

Centering the Black schoolgirl and her needlework is only a portion of what can be discovered about the lives of Black girls and women in antebellum Philadelphia. Pulling on the threads of Mary D'Silver, Adaline Harris and Olevia Rebecca Parker lives reveals their presence in Philadelphia society throughout the nineteenth century. Mary D'Silver disappeared from the archives after she created her embroidery until the death of her mother, Judith, in $1852 .{ }^{47}$ In 1852 , D'Silver would have been approximately sixty-seven years old. Then she disappears from the archives once more. ${ }^{48}$

Adaline Harris finished her time at the Clarkson School at age seventeen. She appears in the archival record in several ways after her graduation. She became a domestic servant and opened a savings account with the Philadelphia Savings Fund Society (PSFS). ${ }^{49}$ Harris remained in service until the age of twenty-five when in 1841 she moved to the Rittenhouse area of the city at the corner of Schuylkill $6^{\text {th }}$ Street and Walnut Street. ${ }^{50}$ Her employment is continued to be listed as "in service." 51 She then disappears from the archives.

Olevia Rebecca Parker appears on the 1860 census, age twenty-two, married Joseph Brister, a prominent Black dentist in the city, as the mother of two children, Olivia and James. ${ }^{52}$ The Brister family remained in Olevia's childhood home at 3 Cobb Street along with her mother, and three of her siblings, one sister, Elizabeth and two brothers, George and Theophilus. ${ }^{53}$ In adulthood Olevia's siblings worked in the city, her sister as a seamstress, and her brothers as a barber and apprentice shoemaker. Given Olevia's needlework and her sister's employment as a seamstress, it

\footnotetext{
${ }^{46}$ Benjamin C. Bacon, "Coloured School Statistics: To the Board of Education of the Pennsylvania Society for Promoting the Abolition of Slavery, etc." E441A58 v.100 no.13. 1853. This is cited in "Without Concealment Without Compromise: The Coloured People of Philadelphia," National Anti-Slavery Standard, August 12, 1854, Accessible Archives.

${ }^{47}$ Further research would involve figuring out if Absalom and Judith D'Silver (nee Jones) are related to one another. An Israel D'Silver is also present in the records of the church, however his connection to Emanuel, Judith, and Mary is not stated nor has been found. Her death certificate is archived in the records of the African Episcopal Church of St. Thomas in Philadelphia. It is likely that the family was associated with the church during their lives in Philadelphia. The African Episcopal Church of St. Thomas, led by Absalom Jones, was one of several institutions that promoted the racial equality of Philadelphia's Black residents and assisted freed residents. The church and its members placed great importance on the education of children and adults in the Black community. See Erica Armstrong Dunbar, A Fragile Freedom, 55. The D'Silvers's probable association with the African Methodist Episcopal Church of St. Thomas in addition to Mary's sampler are evidence of the importance the D'Silvers placed on their daughter's education.

${ }^{48} \mathrm{I}$ have been unable to find her profession or death certificate in the archives.

${ }^{49}$ Historic Pennsylvania Church and Town Records, 1833. It was the first institution of its kind that welcomed free Black people to open their own personal accounts.

${ }^{50}$ Schuylkill $6^{\text {th }}$ Street is now known as $17^{\text {th }}$ Street in Philadelphia.

${ }^{51}$ Historic Pennsylvania Church and Town Records, 1841.

${ }^{52}$ United States Census, Population Schedule. 1860. Ancestry.com. Database on-line. Her husband was an active member of the Philadelphia Savings Fund Society, the Banneker Institute, and the Social Civil and Statistical Association, all prominent organizations for Black Philadelphians.

${ }^{53}$ United States Census, Population Schedule. 1860. Ancestry.com. Database on-line. In this record the family name is spelled 'Bristal' but names and ages link to what is known about the Parker and Brister families. Cobb Street had a name change in 1897 to Lawrence Street, which existed between Queen to Catherine Streets, west of $4^{\text {th }}$ Street in Philadelphia. "DOR - Historic Streets Index." Accessed December 11, 2017. https://www.phillyhistory.org/historicstreets/default.aspx.
} 
is highly likely that they learned as girls not only how to sew but also to value that work from their family. After Olevia's father died, sometime between 1847 and 1860, her mother inherited the family house. Then by the 1863 tax assessment record, the Brister family moved to 844 Lombard Street, a multiracial neighborhood of the Seventh Ward of the city. ${ }^{54}$ Joseph was listed with $\$ 500$ in personal estate and paid taxes on the real estate ${ }^{55} \mathrm{He}$ also practiced dentistry at 606 Pine Street in the city. Olevia and Joseph's eldest daughter, Olivia, was a teacher and son, James, was a dentist like his father by the recording of the 1880 census. James became a student at the University of Pennsylvania School of Dentistry in 1879 and completed his studies in 1881 becoming a founding member of the alumni society. He was known as the first African American to graduate from the school of dentistry. Today the alumni society at the University of Pennsylvania is named after him as the James Brister Society.

By 1885, Olevia and her daughter Olivia were members of the Crucifixion Episcopal Church located at $8^{\text {th }}$ and Bainbridge Streets in the city. Olevia died five years later in 1890 and was buried at Olive Cemetery. ${ }^{56}$ Olevia Rebecca Parker died at the age of fifty-six years old. She was survived by her husband, Joseph and four children Olivia, James, Theophilus, and Angela.

Needlework offers invaluable insight into the early education of Black American girls and young women prior to Emancipation. These three embroideries are examples of cultural production from the youngest Black residents of the United States of America between the Revolutionary War and the Civil War. They are exceptional for their rarity, their artisanship, and for their representation of young Black girls learning in early America. When interdisciplinary methodologies are utilized the lives of Black girls and young women are made visible negating the very intentional erasure of Black people from the traditional archives. Therefore, this is political work grounded in Black feminist-womanist theories and methodologies that marry historical methods centering the archives with material and visual cultural analysis. Through this coupling, the presence, voices, and lived experiences of Mary D'Silver, Adaline Harris, Olevia Rebecca Parker and their families in antebellum Philadelphia are revealed. As Alice Walker states, "We have constantly looked high, but we should have looked high and low." 57 The evidence of Black girls and women's creative spirits, their presence, their joy, their "respect for the possibilities" is inherited and all around us. ${ }^{58}$

\footnotetext{
${ }^{54}$ Internal Revenue Assessment Lists for Pennsylvania, 1862-1866, National Archives Microfilm Publication M787. Record Group 58, Records of the Internal Revenue Service. The family lived amongst a native-born white family of undocumented ancestry, German, Irish, Black, and Mulatto families of low/middle to upper class status.

55 This would be approximately $\$ 10,332.86$ in 2020 according to inflation calculator, https://www.in2013dollars.com/. Olevia was listed as "keeping house" and the family of six lived in the home with three Black domestic servant women by the time of the 1870 census.

${ }^{56}$ Olive Cemetery was located on the western side of the Schuylkill River. Its remains were moved to the Historic Eden Cemetery in suburban Delaware County at the end of the nineteenth century. This was the beginning of the Jim Crow era in the north when racist city ordinances closed the burial places of African Americans at the Lebanon and Olive Cemeteries; and enacted a municipal ordinance that prohibited the creation of new African American cemeteries within city limits. For more information see, "Historic Eden Cemetery - Beginnings." Accessed December 4, 2020. https://www.edencemetery.org/beginnings.

${ }^{57}$ Alice Walker, In Search of Our Mothers' Gardens: Womanist Prose (San Diego: Harcourt Brace Jovanovich, 1983), 239.

${ }^{58}$ Walker, In Search of Our Mothers' Gardens, 242.
} 


\section{Bibliography}

Adamson, Peter. "Souleymane Bachir Diagne on Islam in Africa." History of Indian and African Philosophy. Podcast. August 8, 2020. https://historyofphilosophy.net/diagne-islam-africa.

Allen, Gloria Seaman. A Maryland Sampling: Girlhood Embroidery 1738-1860. Baltimore, Md: The Maryland Historical Society, 2007.

Bacon, Benjamin C. "Coloured School Statistics: To the Board of Education of the Pennsylvania Society for Promoting the Abolition of Slavery, etc." 1853. E441A58 v.100 no.13. Historical Society of Pennsylvania. Retrieved January 12, 2021. https://digitallibrary.hsp.org/index.php/Detail/objects/8298.

Capshaw, Katharine and Anna Mae Duane. "Introduction: The Radical Work of Reading Black Children in the Era of Slavery and Reconstruction." In Who Writes for Black Children?: African American Children's Literature before 1900. Minneapolis, MN: University of Minnesota Press, 2017.

Christ Church of Philadelphia. Register of Marriages. 1709-1800. Pp. 4447.

Christ Church of Philadelphia. Register of Baptisms. 1769-1794. Pp. 1220.

Convention of Delegates from the Abolition Societies Established in Different Parts of the United States. 1797. Minutes of the Proceedings of a Convention of Delegates from the Abolition Societies Established in Different Parts of the United States. 4: 31-34.

Philadelphia, PA: Zachariah Poulson. Retrieved January 12, 2021

(https://archive.org/details/minutesofproceed00conv/page/n7/mode/2up).

Crucifixion Episcopal Church. Baptism, Communicants, Confirmations, Marriages, Families, and Burials, 1848-1958. 1885. MfilmXCh486. Historical Society of Pennsylvania.

Du Bois, W. E. B, Elijah Anderson, and Isabel Eaton. The Philadelphia Negro: A Social Study. Reprint. Philadelphia, PA: University of Pennsylvania Press, 1996.

Dunbar, Erica Armstrong. A Fragile Freedom: African American Women and Emancipation in the Antebellum City. New Haven: Yale University Press, 2008.

Farrington, Lisa E. Creating Their Own Image: The History of African-American Women Artists. Oxford, England: Oxford University Press, 2005.

Friends Historical Library of Swarthmore College. Philadelphia Yearly Meeting (Orthodox) Representative Committee Records. RG2/Pho. 1847. Philadelphia African American Census.

Gillow, John. African Textiles. San Francisco: Chronicle Books, 2003. 
Glymph, Thavolia. Out of the House of Bondage: The Transformation of the Plantation Household. Cambridge, UK: Cambridge University Press, 2003.

Hampton, Karen. "African American Women: Plantation Textile Production from 1750 to 1830." Approaching Textiles, Varying Viewpoints: Proceedings of the Seventh Biennial Symposium of the Textile Society of America 770 (2000): 262-71.

Harris, Jennifer. Textiles, 5,000 Years :An International History and Illustrated Survey. New York: Harry N. Abrams, Inc., 1993.

Hartman, Saidiya. "Venus in Two Acts." Small Axe: A Caribbean Journal of Criticism Small Axe: A Caribbean Journal of Criticism 26, no. 3 (2008): 1-14.

Hine, Darlene Clark. "Rape and the inner lives of Black women in the Middle West: preliminary thoughts on the culture of dissemblance." Signs 14, no. 4 (1989): 912-20.

Historic Pennsylvania Church and Town Records. 1833. Historical Society of Pennsylvania. -----. 1841. Historical Society of Pennsylvania.

Internal Revenue Assessment Lists for Pennsylvania. 1862-1866. National Archives Microfilm Publication M787. Record Group 58. Records of the Internal Revenue Service.

Morgan, Jennifer L. Laboring Women: Reproduction and Gender in New World Slavery. Philadelphia: University of Pennsylvania Press, 2004.

Nash, Gary B. Forging Freedom: The Formation of Philadelphia's Black Community, 17201840. Cambridge, Mass.: Harvard University Press, 1988.

Owens, Tammy C., Durell C. Callier, Jessica L. Robinson, and Porshe R. Garner. "Towards an Interdisciplinary Field of Black Girlhood Studies." Departures in Critical Qualitative Research 6, no. 3 (2017): 116-32.

Pennsylvania Abolition Society Papers, 0490. "Pennsylvania Abolition Society Board of Education, Clarkson School - Entrance of Girls 1828-1838.” AMS.183. Historical Society of Pennsylvania.

Philadelphia Board of Education. Date. Minutes of the directors of public schools, 1827-1841. Pp. 33, 35. Kennedy Center.

Picton, John, and John Mack. African Textiles: Looms, Weaving and Design. London: British Museum Publications for the Trustees of the British Museum, 1979.

Rovine, Victoria L. "West African Embroidery: History, Continuity, and Innovation." Pp. 57-73 in Africa Interweave: Textile Diasporas, exhibition catalog edited by Susan Cooksey. Gainesville, FL: Samuel P. Harn Museum of Art, University of Florida, 2011.

Schiffer, Margeret B. Historical Needlework of Pennsylvania. New York: Scribner, 1968. 
Segalo, Puleng. "Women Speaking through Embroidery: Using Visual Methods and Poetry to Narrate Lived Experiences." Qualitative Research in Psychology 15, no. 2-3 (July 3, 2018): 298-304. https://doi.org/10.1080/14780887.2018.1430013.

Skedd, S. J. "More, Hannah (1745-1833), Writer and Philanthropist.” Oxford Dictionary of National Biography. Accessed January 26, 2021. https://doi.org/10.1093/ref:odnb/19179.

Ulrich, Laurel Thatcher. The Age of Homespun: Objects and Stories in the Creation of an American Myth. Vintage, 2009.

United States Census, Population Schedule. 1860. Ancestry.com. Database on-line.

-----. 1870. Ancestry.com. Database on-line.

-----. 1880. Ancestry.com. Database on-line.

Van Horne, John C. "The Education of African Americans in Benjamin Franklin's Philadelphia." In "The Good Education of Youth": Worlds of Learning in the Age of Franklin, edited by John Pollack, 72-99. Philadelphia, PA: Oak Knoll Press, University of Pennsylvania Libraries, 2009.

Van Horne, John C and Associates of Dr. Bray. Religious Philanthropy and Colonial Slavery: The American Correspondence of the Associates of Dr. Bray : 1717-1777. Urbana, Chicago, IL: University of Illinois Press, 1985.

Walker, Alice. In Search of Our Mothers' Gardens: Womanist Prose. San Diego: Harcourt Brace Jovanovich, 1983.

Wheatley, Phillis. Poems on Various Subjects, Religious and Moral. Re-printed ed. Albany, NY: Barber \& Southwick, 1773/1793.

Winterthur Museum Collection Digital Database. File: 2009.0012.001A-B. Needlework Picture, 2009.

------. File: 2014.0033 A-B. Sampler (Marking Sampler), 2014.

Wolfe, Brendan. “Associates of Dr. Bray.” In Encyclopedia Virginia. Virginia Humanities, 2017. https://www.encyclopediavirginia.org/Associates_of_Dr_Bray. 